\title{
Penggunaan Pembelajaran Problem Based Learning (PBL) Untuk Mengurangi Miskonsepsi Pada Materi Asam Basa
}

\author{
Dewi Yul Launde ${ }^{* a}$, Emma J. Pongoh ${ }^{a}$, Jeanne M. Tuerah ${ }^{a}$
}

a Pendidikan Kimia, FMIPA, Universitas Negeri Manado, Minahasa, Tondano Selatan, 95618, Indonesia

INFO ARTIKEL

Diterima 11 Februari 2020

Disetujui 29 Desember 2020

\section{Keywords:}

Misconception

Acid-base

Problem Based Learning

Rasch model

Kata kunci:

Miskonsepsi

Asam basa

Problem-based learning

Rasch model

\begin{abstract}
A B S T R A C T
This study aimed to find out the effects of Problem Based Learning on reducing students' misconceptions to acid-base material. Problem-based learning (PBL) used in this study. Students of SMA Katolik Karitas Tomohon was the population and sample of this study; students of grade XII Science as a population and students of grade XII 2 Science as a sample. The results of this study were analyzed using Rasch Model and hypothesis testing. The results of this study showed that students with misconceptions still there even students with high capability. The average pretest score $=48.6$ while the average for posttest $=86.8$. This study used T-test statistic to find out hypothesis test analyzes with 0.05 as a significant level and $T_{\text {count }} 7.90>$ 1.684 as a result that found out which $T_{\text {table }}$ means $H_{0}$ rejected and $H_{1}$ was accepted. Based on this study, the conclusion was that the problem-based learning model would help reduce students' misconceptions on acid-base material.
\end{abstract}

${ }^{*}$ e-mail:

dewiyullaunde17@gmail.com

\begin{abstract}
A B STRAK
Penelitian ini bertujuan untuk mengetahui pengaruh penggunaan pembelajaran Problem Based Learning terhadap pengurangan miskonsepsi siswa pada materi asam basa. Model pembelajaran yang digunakan dalam penelitian ini adalah model pembelajaran Problem Based Learning (PBL). Populasi dalam penelitian ini adalah seluruh siswa kelas XII IPA di SMA Katolik Karitas Tomohon sedangkan sampel yang digunakan yaitu kelas XII IPA 2. Analisis data yang digunakan dalam penelitian ini adalah Rasch model dan uji hipotesis. Hasil penelitian menunjukan bahwa masih ada siswa yang mengalami miskonsepsi bahkan termasuk siswa yang memiliki kemampuan yang tinggi, dan rata-rata hasil belajar pretest $=48.6$ sedangkan rata-rata hasil belajar Posttest $=86.6$. Hasil penelitian untuk uji hipotesis dianalisis menggunakan statistik uji-T pada taraf signifikan 0.05 dan hasil yang diperoleh yaitu diperoleh Thitung $7.90>1.684$ tabel sehingga $\mathrm{H}_{0}$ ditolak dan $\mathrm{H}_{1}$ diterima. Berdasarkan hasil tersebut maka dapat disimpulkan bahwa penggunaan model pembelajaran Problem Based Learning dapat mengurangi miskonsepsi siswa.
\end{abstract}

\section{Pendahuluan}

Perkembangan dunia modern menuntut semua orang untuk memiliki pendidikan yang baik agar dapat bersaing dalam dunia pekerjaan secara nasional maupun internasional. Pendidikan juga sangat penting karena mempunyai peranan besar dalam perkembangan individu. Salah satu wadah pendidikan adalah sekolah, dan mata pelajaran kimia adalah mata pelajaran wajib untuk siswa yang mengambil jurusan IPA. Kimia adalah ilmu sains yang mempelajari tentang sifat, struktur, dan perubahan materi serta energi yang menyertai reaksi tersebut.

Siswa mengenal pelajaran kimia pada tahapan SMA. Masih terdapat siswa memiliki minat belajar yang kurang untuk mata pelajaran kimia karena mereka merasa tidak penting untuk belajar kimia. Hal ini juga dikuatkan dengan hasil penelitian yang membuktikan 
siswa merasa kesulitan dalam mempelajari materi kimia seperti reaksi redoks, larutan penyangga, dan titrasi asam basa, ini disebabkan karena rendahnya pemahaman siswa tentang konsep kimia yang benar [1-6].

Pemahaman konsep kimia bagi siswa sering ditemukan miskonsepsi. Miskonsepsi adalah sesuatu konsep yang tidak sesuai dengan pengertian ilmiah atau yang tidak sesuai dengan teori para ahli. Miskonsepsi sangat sulit dirubah karena konsep tersebut sudah tertanam sangat kuat dalam pola pikir (alam pikir) siswa sebagai konsep yang benar. Ilmu kimia bersifat sistematis sehingga konsepnya saling berhubungan satu dengan yang lain, itu sebabnya jika terjadi miskonsepsi pada siswa dapat berakibat fatal karena memungkinkan munculnya miskonsepsi pada materi kimia yang lain [7,8]. Selanjutnya berdasarkan penelitian sebelumnya terbukti masih didapati siswa yang mengalami miskonsepsi pada materi kimia seperti reaksi reduksi oksidasi, dan asam basa, sifat keasaman larutan garam [1,7,9-13]. Penyebab miskonsepsi siswa karena konsepsi awal siswa yang salah dan kemampuan siswa $[9,14]$. Miskonsepsi terjadi pada siswa karena dikembangkan dari berbagai sumber, seperti pengalaman pribadi (pengamatan), interaksi teman sebaya, dan model pengajaran yang salah [10].

Pembelajaran berbasis masalah cocok digunakan dalam pembelajaran kimia karena mengangkat masalah di dunia nyata dan mengaitkannya dengan pelajaran serta dapat meningkatkan partisipasi siswa dan minat belajar siswa baik dalam kelas atau luar kelas [15]. Berdasarkan hasil observasi dan wawancara dengan ibu Yanti sebagai guru kimia kelas XI yang mengatakan bahwa siswanya masih memiliki kesalapahaman konsep pada materi asam basa dan merasa kesulitan dalam perhitungan $\mathrm{pH}$. Hal inilah yang melatarbelakangi keinginan penulis untuk melakukan penelitian di sekolah SMA Katolik Karitas Tomohon agar dapat menganalisis miskonsepsi siswa pada materi kimia asam basa khususnya kelas XII IPA 2, serta ingin memperbaiki atau mengurangi miskonsepsi siswa dengan menggunakan pembelajaran Problem Based Learning (PBL).

\section{Metode Penelitian}

Penelitian ini dilakukan di SMA Katolik Karitas Tomohon pada tanggal 25 September 2019 - 14 Oktober 2019. Jenis penelitian ini adalah deskriptif kuantitatif dengan desain penelitian "one group pretest-posttest". Setiap soal yang diberikan diuji validitas dan reliabilitas. Soal kemudian diujikan kepada siswa dengan system pretest dan posttest.

\section{Hasil dan Pembahasan}

\section{Hasil Penelitian}

Penelitian ini menggunakan model pembelajaran Problem Based Learning (PBL) dengan tujuan untuk mengurangi miskonsepsi siswa pada materi asam basa. Instrumen yang digunakan untuk menganalisis miskonsepsi adalah tes diagnostic two-tier dan menggunakan 1 kelas yaitu kelas XII IPA 2 SMA Katolik Karitas Tomohon dengan 23 responden. Pengambilan data penelitian ini yaitu untuk mengetahui miskonsepsi siswa pada materi asam basa dengan menggunakan rasch model dan pengaruh penggunaan pembelajaran problem based learning untuk mengurangi miskonsepsi siswa pada materi asam basa dengan menggunakan uji t.

\section{Uji Instrumen Penelitian}

\section{Uji Validitas}

Uji Validitas soal pretest dan posttest menggunakan uji ahli dimana dari 20 soal pilihan ganda terdapat 3 soal yang tidak valid dan 17 soal yang valid. Maka, peneliti menggunakan 17 soal sebagai pengukur kemampuan siswa.

\section{Uji Reliabilitas}

Uji reliabilitas instrument menggunakan analisis rasch model dan didapat hasilnya 0.86 yang kriterianya bagus atau instrument yang diukur reliable.

\section{Pengambilan Data}

Data diperoleh melalui hasil belajar siswa pada materi asam basa dari hasil pretest dan posttest. Deskripsi data hasil analisis pretest dan posttest ditunjukkan dalm tabel 1. 
Tabel 1. Data hasil belajar pretest dan posttest

\begin{tabular}{llll}
\hline No & Statistik & Posttest & Pretest \\
\hline 1 & Skor Minimum & 41 & 20 \\
\hline 2 & $\begin{array}{l}\text { Skor } \\
\text { Maksimum }\end{array}$ & 100 & 75 \\
\hline 3 & Rata-rata & 86.57 & 48.57 \\
\hline 4 & Varians (s $\left.{ }^{2}\right)$ & 218.71 & 223.62 \\
\hline 5 & $\begin{array}{l}\text { Simpangan } \\
\text { baku (s) }\end{array}$ & 14.79 & 14.95 \\
\hline
\end{tabular}

Berdasarkan tabel 1 rata-rata hasil posttest dan pretest adalah 85,57 dan 48,57 . Selanjutnya, hasil pretest dan posttest diuji dengan analisis rasch model yaitu menggunakan output tables item scalogram dan output tables item measure yang berfungsi untuk memudahkan dalam menganalisis, memprediksi kemampuan individu dan tingkat kesulitan soal serta menyatakan jumlah jawaban benar pada butir soal sesuai aplikasi Ministep.

\section{Uji Normalitas}

Pada penelitian ini, uji normalitas yang dipakai adalah uji Liliefors. Kriteria data menyebar normal jika Lhitung $<$ Ltabel, dan taraf nyata yang digunakan dalam penelitian ini yaitu 0.05 dan ditunjukkan dalam tabel 2 .

Tabel 2. Uji Normalitas hasil belajar

\begin{tabular}{lll}
\hline $\begin{array}{l}\text { Uji Liliefors Nilai } \\
\text { Lhitung }\end{array}$ & $\begin{array}{l}\text { Nilai } \\
\text { Ltabel }\end{array}$ & Kesimpulan \\
\hline 0.135 & 0.173 & Terima $\mathrm{H}_{0}$ \\
\hline
\end{tabular}

\section{Uji Hipotesis}

Uji hipotesis digunakan untuk melihat pengaruh penggunaan pembelajaran problem based learning (PBL) terhadap miskonsepsi siswa pada materi asam basa.

Tabel 3. Ringkasan data uji hipotesis

\begin{tabular}{lcc}
\hline \multicolumn{1}{c}{ Variabel } & Posttest & Pretest \\
\hline $\mathrm{N}$ & 23 & 23 \\
\hline $\mathrm{n}-1$ & 22 & 22 \\
\hline Rata-rata & 86.57 & 48.57 \\
\hline Varians $\left(\mathrm{s}^{2}\right)$ & 218.71 & 223.62 \\
\hline Nilai t & tabel $=1.68$ & thitung $=7.902$ \\
\hline
\end{tabular}

Hipotesis Statistik:

$H_{0}=\mu_{1} \leq \mu_{2}$
$H_{1}=\mu_{1}>\mu_{2}$

Keterangan:

$\mu_{1}$ : Rata-rata hasil belajar posttest

$\mu_{2}$ : Rata-rata hasil belajar pretest

Hasil pengujian hipotesis pada tabel 3 dengan uji $t$, diperoleh thitung $=7.902$ dan nilai tabel pada taraf nyata $(\alpha)=0.05$ adalah 1.68 . Jadi, thitung $>$ tabel maka terima $\mathrm{H}_{1}$ yaitu: $\mu_{1}>\mu_{2}$, dan tolak $\mathrm{H}_{0}$.

\section{Pembahasan}

Konsep awal siswa didapatkan saat berada di sekolah dasar, sekolah menengah, serta pengamatan mereka dalam kehidupan seharihari. Miskonsepsi adalah suatu interpretasi atau suatu konsep tertentu yang tidak akurat dan tidak sejalan dengan pengertian yang diterima secara umum. Mata pelajaran kimia sendiri masih terdapat miskonsepsi untuk materi tertentu, itu dibuktikan dengan penelitianpenelitian sebelumnya yang menyatakan terjadi miskosepsi untuk materi kimia contohnya struktur atom, redoks, stoikiometri dan asam basa $[2,5,9,16]$.

Data pretest yang diperoleh dalam penelitian ini melalui tes diagnostik two-tier sangat bervariasi antara persentase siswa yang paham konsep dan tidak paham konsep serta miskonsepsi, dari hasil penelitian didapatkan persentase rata-rata siswa yang paham konsep, miskonsepsi, dan tidak paham konsep pada materi asam basa berturut-turut, yaitu $26 \%$, $29 \%$, dan $45 \%$.

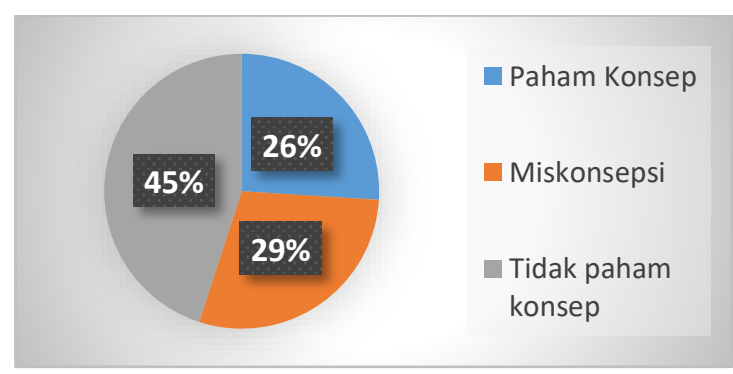

Gambar 1. Diagram presentase pemahaman konsep siswa keseluruhan

Gambar 1 menyatakan bahwa banyak siswa yang belum memahami konsep dan masih ada siswa juga yang memiliki miskonsepsi bahkan presentasi siswa yang mengalami miskonsepsi dan paham konsep hampir sebanding. Selajutnya, berdasarkan 
analisis rasch model item measure menunjukan bahwa siswa mengalami miskonsepsi tertinggi pada soal nomor 15 (Gambar 2).

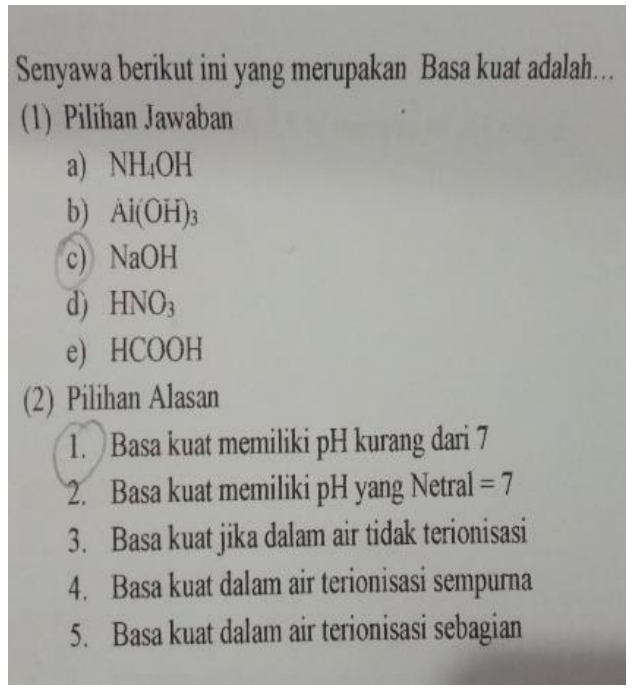

Gambar 2. Soal dan hasil jawaban siswa (nomor 15)

Pada soal ini dari 23 siswa 14 siswa yang mengalami miskonsepsi. Soal nomor 15 siswa diminta untuk menentukan senyawa yang merupakan basa kuat dan ada siswa yang menjawab $\mathrm{Al}(\mathrm{OH})_{3}$ dan $\mathrm{HCOOH}$ adalah senyawa basa kuat dengan alasan yang salah seperti basa kuat memiliki pH kurang dari 7 dan basa kuat memiliki $\mathrm{pH}$ yang netral $=7$, ini menunjukan bahwa siswa belum bisa membedakan mana basa lemah dan basa kuat serta mana senyawa asam mana senyawa basa, yang membuat mereka salah menjawab soal. Berdasarkan jawaban siswa membuktikan bahwa pemahaman siswa untuk materi kimia tentang kekuatan asam basa sangat lemah. Hal ini sejalan dengan penelitian sebelumnya yang menyatakan bahwa lemahnya pemahaman siswa tentang kekuatan asam membuat siswa kesulitan untuk membedakan asam lemah dengan asam kuat, basa lemah dengan basa kuat [17]. Selanjutnya hal yang sama juga terjadi untuk soal nomor 8 dimana tidak ada siswa yang mampu menjawab dengan benar (Gambar 3).

Berdasarkan jawaban siswa di atas, menjelaskan bahwa siswa tersebut mengalami miskonsepsi karena mampu menjawab benar pilihan alasan tapi tidak mampu menjawab dengan benar pilihan jawaban. Ini mengkonfirmasi bahwa seluruh siswa tidak memahami dengan benar konsep asam basa
Arrhenius. Selain itu, ini membuktikan bahwa siswa belum mampu untuk membedakan mana senyawa bersifat asam menurut Arrhenius walaupun pilihan alasan dari siswa ini benar tetapi dapat dilihat kemungkinan bahwa siswa hanya menghafalkan teori asam basa tetapi dalam reaksi kimia siswa masih belum mampu untuk menentukan mana senyawa asam dan mana senyawa basa.

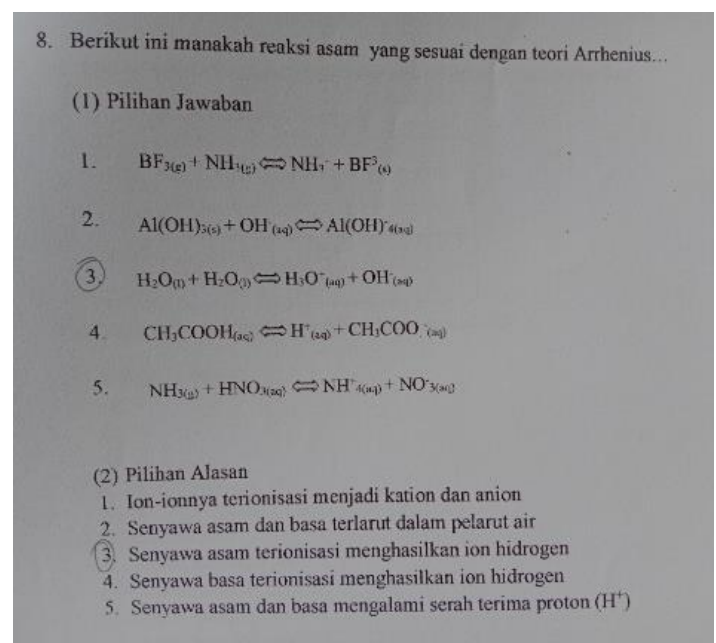

Gambar 3. Soal dan hasil jawaban siswa (nomor 8)

Selanjutnya, soal nomor 7 dan 8 membahas tentang teori asam basa Brosted-Lowry dan terdapat juga siswa yang mengalami mikonsepsi karena siswa belum mampu untuk menentukan mana senyawa yang bersifat asam dan basa serta pasangan konjugasinya menurut Bronsted-Lowry. Hal ini sejalan dengan penelitian yang mengatakan bahwa siswa kesulitan dalam pendefinisian asam basa menurut Arrhenius karena kemungkinan siswa tidak dapat membedakan pengertian asam basa menurut beberapa teori asam yang dipelajari dan siswa juga tidak dapat menggolongkan suatu senyawa bersifat asam dan basa dalam reaksi ionisasinya[18].

Berdasarkan hasil pretest pada analisis rasch model Scalogram dan measure, dimana rasch model telah mengurutkan siswa yang memiliki kemampuan tertinggi adalah siswa $06 \mathrm{~L}$ dan siswa yang memiliki kemampuan terendah adalah siswa $12 \mathrm{P}$, sedangkan soal yang sulit adalah soal nomor 14 (gambar 4).

Soal nomor 14 mengkonfirmasi pemahaman siswa tentang konsep asam basa pada tetapan ionisasi. Berdasarkan hasil analisis 
item measure terlihat dari 23 siswa 22 siswa tidak dapat menjawab dengan benar soal nomor 14, dimana 14 siswa menjawab (B) artinya bahwa kedua larutan tersebut memiliki kekuatan asam yang sama dan 12 siswa menjawab dengan alasan nomor (1) yaitu kedua larutan tersebut merupakan larutan asam dengan kekuatan asam yang sama. Ini artinya siswa masih merasa kesulitan untuk memahami materi asam basa khususnya pada konsep ionisasi. Bahkan, siswa yang memiliki kemampuan yang tinggi seperti 06L, 10L, 15P, dan 20L juga secara bersamaan tidak dapat menyelesaikan dengan benar atau mengalami miskonsepsi pada soal nomor 14, 9,15, 8 dan 18 itu terlihat pada hasil analisis rasch model scalogram. Soal nomor 18 tentang perhitungan $\mathrm{pH}$, terdapat pada gambar no 5 .

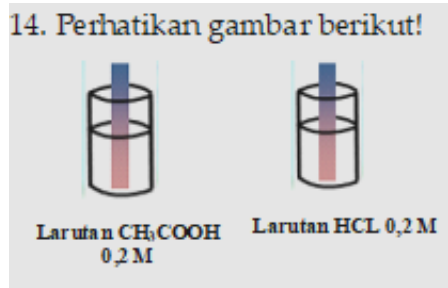

Apakah kedua larutan tersebut memiliki kekuatan asam yang berbeda?

(1) Pilihan jawaban
A. Ya
B. Tidak

(2) Pilihan Alasan

1. Keduanya merupakan larutan asam dengan kekuatan asam yang sama

2. Banyaknya atom yang berikatan memengaruhi kekuatan asam

3. Kemampuan terionisasi dalam air yang berbeda mempengarthi kekuatan asam

4. Konsentrasi larutan yang sama mengakibatkan kekuatan asamnya sama

5. Asam asetat memiliki jumlah atom Hidrogen lebih banyak dibandingkan dengan Asam klorida.

\section{Gambar 4. Soal no 14}

Berdasarkan pilihan jawaban siswa pada gambar 5 yaitu D, dan pilihan alasan 5, menunjukan bahwa siswa belum mampu untuk menentukan $\mathrm{pH}$ basa lemah walaupun pilihan alasannya benar, itu dapat dilihat berdasarkan konsep berpikir siswa lewat uraian jawaban pada gambar di atas. Pilihan alasan yang disajikan merupakan tahapan-tahapan berupa rumus ataupun nilai yang digunakan dalam menyelesaikan soal. Selanjutnya berdasarkan gambar 5 siswa memilih pilihan jawaban salah tetapi pilihan alasan benar, ini memungkinkan siswa hanya menebak/mengikuti jawaban teman berdasarkan pilihan rumus dan nilai yang tersedia pada pilihan alasan, itu dapat dilihat dari uraian jawaban siswa di kertas dimana nilai pOH-nya bukan 5 tetapi $3 \log 10$ dan pilihan jawabannya $5+\log 3$ yang tentunya tidak mengikuti tahapan rumus atau nilai yang digunakan dalam soal. Hal ini juga sejalan dengan penelitian yang menjelaskan bahwa siswa mengalami kesulitan yang tinggi dalam memahami materi $\mathrm{pH}$ larutan asam basa khususnya konsep hitungan, ini disebabkan karena kurangnya tingkat ketelitian siswa, kurangnya kemampuaan siswa dalam menentukan dan mengaplikasikan rumus dalam mengerjakan soal hitungan, dan kurangnya pemahaman siswa untuk memahami dan mengerjakan soal bertingkat [18].

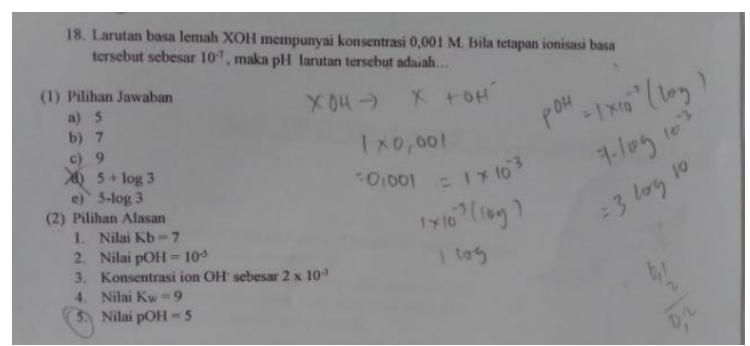

Gambar 5. Soal dan jawaban siswa (nomor 18)

Berdasarkan uraian di atas dapat dilihat bahwa masih terdapat miskonsepsi dan tidak paham konsep siswa untuk materi asam basa bahkan untuk siswa yang memiliki kemampuan tinggipun masih mengalami miskonsepsi untuk konsep tertentu. Dan dalam penelitian ini peneliti mengajarkan menggunakan pembelajaran problem based learning (PBL) untuk melihat pengaruhnya dalam mengurangi miskonsepsi siswa pada materi asam basa karena pembelajaran problem based learning (PBL) memiliki kelebihan yaitu memberikan motivasi belajar kepada siswa, siswa dilatih untuk memiliki tanggung jawab 
yang tinggi untuk belajar, siswa belajar untuk berbagi dan bertukar ide mereka dengan orang lain, siswa aktif berpartisipasi dalam belajar, serta siswa diajar untuk memiliki kemampuan menyelesaikan masalah. Hasil dari penelitian ini menunjukan adanya perbedaan yang signifikan dari sebelum menggunakan pembelajaran problem based learning dan setelah menggunakan problem based learning, itu dilihat dari pengujian hipotesis (uji T) pada tabel 3, dimana pada taraf $\alpha=0.05$ diperoleh thitung $=$ $7.902>$ tabel 1.68 , sehingga $\mathrm{H}_{0}$ ditolak dan $\mathrm{H}_{1}$ diterima. Hasil pengujian hipotesis dapat dilihat bahwa penggunaan pembelajaran problem based learning terhadap miskonsepsi siswa memberikan pengaruh yang baik dalam penurunan miskonsepsi siswa pada materi asam basa dibandingkan sebelumnya. Hal ini juga sejalan dengan hasil yang dilihat dari analisis rasch model item measure dan scalogram pada lampiran 11 yang menunjukan terjadi penurunan miskonsepsi dari $29 \%$ berkurang menjadi $10 \%$, dan penurunan tidak paham konsep dari $45 \%$ menjadi $8 \%$ serta kenaikan pemahaman konsep dari $26 \%$ menjadi $82 \%$.

\section{Kesimpulan}

Berdasarkan analisis Rasch model presentase siswa yang mengalami miskonsepsi pada materi asam basa yaitu $29 \%$. Presentase miskonsepsi berdasarkan individual item, paling tinggi terdapat pada item nomor 15 . Berdasarkan uji $\mathrm{t}$ dapat disimpulkan bahwa penggunaan model pembelajaran problem based learning (PBL) dapat mengurangi miskonsepsi siswa kelas XII IPA 2 di SMA Katolik Karitas Tomohon pada materi asam basa.

\section{Daftar Pustaka}

1. Mentari, L.; Suardana, I.N.; Subagia, I.W. Analisis Miskonsepsi Siswa SMA Pada Pembelajaran Kimia Untuk Materi Larutan Penyangga. Jurnal Pendidikan Kimia Undiksha 2017, 1, 67-87.

2. Astuti, R.T.; Marzuki, H. Analisis Kesulitan Pemahaman Konsep Pada Materi Titrasi Asam Basa Siswa SMA. Orbital: Jurnal Pendidikan Kimia 2017, 1, 22 27.

3. Al-Balushi, S.M.; Ambusaidi, A.K.; Al-
Shuaili, A.H.; Taylor, N. Omani Twelfth Grade Students' Most Common Misconceptions in Chemistry. Science Education International 2012, 23, 221-240.

4. Astuti, F.; Redjeki, T.; Nurhayati, N.D. Identifikasi Miskonsepsi Dan Penyebabnya Pada Siswa Kelas XI Mia SMA Negeri 1 Sukoharjo Tahun Pelajaran 2015/2016 Pada Materi Pokok Stoikiometri. Jurnal Pendidikan Kimia Universitas Sebelas Maret 2016, 5, 10-17.

5. Barke, H.-D. Two Ideas of the Redox Reaction: Misconceptions and Their Challenge in Chemistry Education. African Journal of Chemical Education 2012, 2, 32-50.

6. Duis, J.M. Organic Chemistry Educators' Perspectives on Fundamental Concepts and Misconceptions: An Exploratory Study. Journal of Chemical Education 2011, 88, 346-350.

7. Sutrisno, S.; Muchson, M.; Widarti, H.R.; Sulistina, O. Miskonsepsi Sifat Keasaman Larutan Garam Pada Guru Kimia Dan Rekonstruksi Konseptualnya. J-PEK (Jurnal Pembelajaran Kimia) 2018, 3, 10-18.

8. Nicoll, G. A Report of Undergraduates' Bonding Misconceptions. International Journal of Science Education 2001, 23, 707730.

9. Kusumawati, I.; Enawaty, E.; Lestari, I. Miskonsepsi Siswa Kelas XII SMA Negeri 1 Sambas Pada Materi Reaksi Reduksi Oksidasi. Jurnal Pendidikan dan Pembelajaran Khatulistiwa 2014, 3.

10. Hwa, T.H.; Karpudewan, M. Green Chemistry-Based Dual-Situated Learning Model: An Approach that Reduces Students' Misconceptions on Acids and Bases. In Overcoming Students' Misconceptions in Science; Springer, 2017; pp. 133-155.

11. Fajarianingtyas, D.A.; Herowati, H.; Yuniastri, R. Gaya Belajar Dan Msikonsepsi Siswa Pada Konsep Redoks Di SMA N 1 Sumenep. LENSA (Lentera Sains): Jurnal Pendidikan IPA 2017, 7.

12. Özmen, H. Some Student Misconceptions in Chemistry: A Literature Review of Chemical Bonding. Journal of Science Education and Technology 2004, 13, 147-159. 
13. SATILMIŞ, Y. Misconceptions about Periodicity in Secondary Chemistry Education: The Case of Kazakhstan. International Online Journal of Primary Education (IOJPE) ISSN: 1300-915X 2014, 3.

14. Tümay, H. Reconsidering Learning Difficulties and Misconceptions in Chemistry: Emergence in Chemistry and Its Implications for Chemical Education. Chemistry Education Research and Practice 2016, 17, 229-245.

15. Tamungku, R.; Tani, D.; Tuerah, J. Analysis of Students' Misconceptions Using Two-Tier Multiple Choice Diagnostic Tests on Atomic Structure Material in Remboken State High School 1. Oxygenius Journal of Chemistry Education 2019, 1, 66-71.

16. Hidayat, F.A.; Irianti, M.; Fathurrahman, F. Analisis Miskonsepsi Siswa Dan Faktor Penyebabnya Pada Pembelajaran Kimia Di Kabupaten Sorong. BASA (Barometer Sains) Jurnal Inovasi Pembelajaran IPA 2020, 1.

17. Utami, F.V.; Saputro, S.; VH, E.S. Analisis Jenis Dan Tingkat Kesulitan Belajar Siswa Kelas XI MIPA SMA N 2 Surakarta Tahun Pelajaran 2018/2019 Dalam Memahami Materi Asam Basa Menggunakan Two Tier Multiple Choice. Jurnal Pendidikan Kimia 2020, 9, 54-60.

18. Amry, U.W.; Rahayu, S.; Yahmin, Y. Analisis Miskonsepsi Asam Basa Pada Pembelajaran Konvensional Dan Dual Situated Learning Model (DSLM). Jurnal Pendidikan: Teori, Penelitian, dan Pengembangan 2017, 2, 385-391.

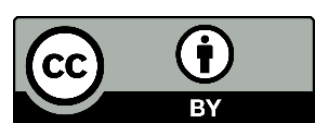

(C) 2020 by the authors. Licensee Oxygenius Journal Of Chemistry Education. This article is an open access article distributed under the terms and conditions of the Creative Commons Attribution (CC BY) license (http://creativecommons.org/licenses/by/4.0/). 